\title{
Sistem Informasi Spesialite Obat (ISO) Indonesia Digital Menggunakan Algoritma Boyer Moore Berbasis Mobile Application
}

\author{
Estu Sinduningrum, Jaka Prayogi, Dimas Febriawan \\ Fakultas Teknik Program Studi Informatika \\ Jalan Tanah Merdeka No.6, Kampung Rambutan, Jakarta Timur \\ estu.ningrum@uhamka.ac.id, jakaprayogi1996@g mail.com, dimas.febriawan@uhamka.ac.id
}

Diterima: 13 Oktober 2018. Disetujui 18 Oktober 2018. Dipublikasikan Nopember 2018

\begin{abstract}
Abstrak - Informasi Spesialite Obat (ISO) Indonesia merupakan alat bantu yang digunakan untuk mencari informasi tentang indikasi, kontra indikasi, dosis pemakaian dan efek samping obat secara lengkap. Penggunaan Informasi Spesialite Obat (ISO) Indonesia sangat diperlukan namun tidak mempersulit pengguna saat menggunakannya dan dapat mempermudah pemakai tanpa harus membawa informasi berbentuk buku yang memiliki ketebalan dan bobot yang cukup berat untuk ukuran sebuah buku. Untuk itu dibutuhkan sebuah aplikasi yang dapat mengakomodir kebutuhan setiap pemakai sebagai pengganti buku, yang mudah dibawa serta dapat digunakan kapan dan dimanapun secara efektif. Aplikasi tersebut berupa Sistem Informasi Spesialite Obat (ISO) Indonesia yang diterbitkan oleh Isfi. Penerbitan berbasis Mobile Application yang dapat dipasang pada perangkat Smartphone. Selain sebagai media komunikasi dalam bentuk panggilan suara atau pesan singkat, dalam perkembangannya merupakan media yang mampu dilengkapi dengan berbagai program aplikasi tambahan untuk kemudahan pengguna. Dalam penelitian ini akan dibahas tentang cara membuat $\mathrm{S}$ istem Informasi $\mathrm{S}$ pesialite Obat (ISO) Indonesia berbasis Mobile Application dengan algoritma Boyer moore. Aplikasi dibangun dengan bahasa pemrograman java, dan Eclipse sebagai editor untuk mengedit kode program. Pengujian terhadap aplikasi ini dan juga implementasi pada Informasi Spesialite Obat (ISO) Digital Apotek Amanah berhasil dilakukan karena Aplikasi pada Smartphone berjalan dengan baik didapatkan $88,83 \%$ responden memberikan penilaian yang baik dalam kinerja aplikasi Sistem Informasi Spesialite Obat Digital dalam menangani permasalahan terkait Informasi obat berbasis Mobile Application yang belum dimiliki dan diketahui oleh Apoteker dan Asisten Apoteker.
\end{abstract}

Kata Kunci: Sistem Informasi Spesialite Obat (ISO) Indonesia, Boyer Moore, Eclipse.

\section{PENDAHULUAN}

Dengan berkembangnya sebuah mobile application sekarang telah mengalami pertumbuhan dan perkembangan yang pesat. Seiring dengan perkembangan teknologi saat ini muncul sistem operasi yang sedang populer digunakan pada perangkat smartphone yaitu IOS, BlackBerry, Windows Phone dan Android. Android merupakan sistem operasi yang bersifat open source sehingga pengembangannya dapat dilakukan dengan luas. Pada kenyataannya perangkat mobile yang menggunakan sistem operasi Android cukup banyak dan dari segi harga lebih terjangkau dibandingkan dengan perangkat mobile sistem operasi lain di Indonesia. Hal ini menjadi pertimbangan untuk membuat aplikasi berbasis mobile application. Permasalahan yang ada pada saat ini seringkali bermunculan nama-nama obat baru yang terkadang kurang dimengerti oleh Apoteker, Asisten Apoteker dan masyarakat pada umumnya. Banyak sekali buku mengenai obat yang beredar tetapi buku tersebut justru menyulitkan karena pengguna harus mencari informasi obat secara manual, yaitu dengan membuka perlembar dari buku tersebut, memakan waktu yang cukup lama dan secara umum tidak dapat mengikuti perkembangan yang ada pada saat ini, tetapi dengan teknologi berbasis mobile application segala informasi bisa berkembang dengan sangat cepat. Untuk itu diperlukan adanya buku informasi obat, agar dapat memudahkan Apoteker dalam mencari penggunaan dosis pemakaian dan efek samping obat. Buku informasi obat tersebut haruslah dapat dengan mudah dipergunakan oleh para pengguna smartphone Android untuk menggunakan aplikasi ISO Digital.

\section{LANDASAN TEORI}

\section{A. Buku Informasi Spesialite Obat (ISO) Indonesia}


Buku ISO Indonesia ini berisi informasi tentang obat yang beredar di Indonesia dengan mencantumkan nama generik atau nama dagang obat yang disertai dengan kekuatan, dosis, aturan pakai, indikasi, kontra indikasi, efek samping, peringatan, perhatian, kemasan yang tersedia serta harga obat di pasaran. Buku ISO Indonesia diharapkan dapat menjadi acuan bagi masyarakat dan tenaga kesehatan khususnya apoteker dalam melakukan pemilihan obat yang tepat dan rasional. Buku ISO Indonesia juga merupakan salah satu alat bantu Apoteker di tanah air untuk melaksanakan nilai-nilai praktik Apoteker yang bertanggung jawab, dimana Apoteker menjamin bahwa obat yang dilayankan bermutu, berkhasiat dan aman bagi pasien. Selain hal tersebut Apoteker juga harus bertanggung jawab melakukan layanan klinis mulai dari screening resep, pengkajian resep, dispensing, pelayanan informasi obat (PIO), konseling, Pelayanan farmasi di rumah (home pharmacy care), pemantauan terapi obat (PTO) dan Monitoring Efek Samping Obat (MESO)[1].

\section{B. Mobile Application}

Mobile application merupakan proses pengembangan aplikasi untuk perangkat genggam seperti PDA, asisten digital perusahaan atau telepon genggam. Aplikasi ini sudah ada pada telepon selama manufaktur, atau di-download oleh pelanggan dari toko aplikasi dan dari distribusi perangkat lunak mobile platform yang lain, yang digunakan pada perangkat smartphone yaitu: IOS, BlackBerry, Windows Phone dan salah satunya Android. Android merupakan sistem operasi yang bersifat open source sehingga pengembangannya dapat dilakukan dengan luas. Pada kenyataannya perangkat mobile yang menggunakan sistem operasi Android yang secara sederhana bis a diartikan sebagai sebuah software yang digunakan pada perangkat mobile yang mencakup sistem operasi, middleware, dan aplikasi kunci yang dirilis oleh Google. Platform pengembangan android ini terbuka, sehingga dapat mengembangkan kemampuan untuk membangun aplikasi yang kaya dan inovatif Sehingga Android mencakup keseluruhan sebuah aplikasi, mu lai dari sistem operasi sampai pada pengembangan aplikasi itu sendiri. Pengembangan aplikasi pada platform Android ini menggunakan dasar Bahasa pemrograman Java, tapi secara sempit android biasanya mengacu pada sistem operasinya saja[2].

\section{Eclipse}

Eclipse adalah sebuah Integrated Development Environment (IDE) untuk mengembangkan perangkat lunak dan dapat dijalankan di semua platform (platform-independent). Eclipse multiplatform dapat berjalan di Windows, Linux, Unix. Eclipse juga me mposisikan sebagai IDE Multilanguage, jadi selain bahasa Java, juga mendukung bahasa $\mathrm{C}++$, Cobol, Fortran. Dapat dikatakan Eclipse ini menjadi sebuah environment untuk pengembangan aplikasi yang berjalan di banyak platform. Konsep Eclipse adalah IDE yang terbuka (open), mudah diperluas (extensible) untuk apa saja, dan tidak untuk sesuatu yang spesifik. Jadi eclipse tidak saja untuk mengembangkan program Java, akan tetapi dapat digunakan untuk berbagai macam keperluan, cukup dengan menginstal plug-in yang dibutuhkan. Apabila ingin mengembangkan program $\mathrm{C} / \mathrm{C}++$ terdapat plugin $\underline{\mathrm{CDT}}$ (C/C++ Development Tools). Dalam pembuatan aplikasi Android, fungsi Eclipse digunakan sebagai IDE (intergrated Development Environment) dengan plug-in yang dapat diimplementasi dalam bahasa pemprograman Java dan pengembangan tampilan visual atau antarmuka [3].

\section{Android Development Tools}

ADT adalah kepanjangan dari Android Development Tools yang menjadi penghubung antara IDE Eclipse dengan Android SDK. ADT ini adalah sebuah plugin untuk Eclipse yang didesain untuk membangun aplikasi Android baru, membuat user interface, menambahkan komponen berdasarkan framework API Android, debug aplikasi dan menjalan kan emulator Android[4].

\section{E. Algoritma Boyer Moore}

Algoritma Boyer Moore termasuk algoritma string matching yang paling efesien dibandingkan algoritma-algoritma string matching lainnya. Algorit ma Boyer-Moore mu lai mencocokkan karakter dari sebelah kanan pattern, karena akan lebih banyak informasi yang didapat. Algoritma Boyer-Moore menggunakan dua fungsi shift yaitu good-suffix dan bad-character shift. Secara sistematis, langka-langkah yang dilakukan algoritma Boyer-Moore pada saat mencocokan string adalah [5] :

1. Algoritma boyer moore mulai mecocokan pattern pada awal teks.

2. Dari kanan kekiri, algoritma ini mencocokan karakter per karakter pattern dengan karakter pada teks yang bersesuaian, sampai salah satu kondisi berikut terpenuhi.

3. Algoritma kemudian menggeser pattern dengan memisalkan nilai pergeseran good-suffix dan pergeseran bad-character lalu mengulangi langkah 2 sampai pattern berada di ujung teks.

Penggunaan algoritma Boyer-Moore dalam melakukan pencarian pattern dalam teks : 
Teks $(\mathrm{S})=$ PERIARTHRITIS

Pattern (P) = RITIS

Tahapan pencarian pattern $(\mathrm{P})$ dalam Teks (S):

TABEL 1. PATT REN, NILAI OH DAN NILAI MH

\begin{tabular}{|l|l|l|l|l|l|}
\hline Pattern $(\mathrm{P})$ & $\mathrm{R}$ & $\mathrm{I}$ & $\mathrm{T}$ & $\mathrm{I}$ & $\mathrm{S}$ \\
\hline Occurence Heuristic $(\mathrm{OH})$ & 3 & 1 & 2 & 1 & 0 \\
\hline Macth Heuristic $(\mathrm{MH})$ & 5 & 5 & 5 & 5 & 1 \\
\hline
\end{tabular}

1. Pergeseran pertama terlihat bahwa algoritma Boyer-Moore memiliki loncatan karakter yang cukup besar sehingga mempercepat proses pencarian. Karakter "S" pada pattern tidak cocok dengan karakter "A" pada teks, maka pergeseran selanjutnya berdasarkan nilai dari tabel $\mathrm{OH}$. Pada tabel OH karakter "A", dapat dilihat pada tabel 2.

TABEL 2. LANGKAH 1

\begin{tabular}{l|l|l|l|l|l|l|l|l|l|l|l|l|l}
\hline \multicolumn{10}{c}{ Langkah ke 1} \\
\hline $\begin{array}{l}\text { Posisi } \\
\text { Teks }\end{array}$ & 1 & 2 & 3 & 4 & 5 & 6 & 7 & 8 & 9 & 10 & 11 & 12 & 13 \\
\hline Teks & P & E & R & I & A & R & T & H & R & I & T & I & S \\
\hline Pattern & R & I & T & I & S & & & & & & & & \\
\hline
\end{tabular}

2. Pada pergeseran ke-2 karakter "S" pada pattern tidak cocok dengan karakter "I" pada teks, maka pergeseran selanjutnya berdas arkan nilai dari tabel $\mathrm{OH}$. Pada tabel $\mathrm{OH}$ karakter "I" terdapat pada tabel, sehingga pergeseran selajutnya adalah sebanyak ju mlah karakter "I" pada tabel $\mathrm{OH}$ pada yaitu 1, dapat dilihat pada tabel 3 .

TABEL 3. LANGKAH 2

\begin{tabular}{l|l|l|l|l|l|l|l|l|l|l|l|l|l|l}
\hline \multicolumn{1}{c}{ Posisi } & 1 & 2 & 3 & 4 & 5 & 6 & 7 & 8 & 9 & 10 & 11 & 12 & 13 \\
\hline Teks & Teks & P & E & R & I & A & R & T & H & R & I & T & I & S \\
\hline Pattern & & & & & & R & I & T & I & S & & & \\
\hline
\end{tabular}

3. Pada pergeseran Ke-3 karakter "S" pada pattern tidak cocok dengan karakter " $\mathrm{T}$ " pada teks, maka pergeseran selanjutnya berdasarkan nilai dari tabel $\mathrm{OH}$. Pada tabel $\mathrm{OH}$ karakter "T" terdapat pada tabel, sehingga pergeseran selajutnya adalah sebanyak jumlah karakter "T" terdapat pada table sehingga pergeseran sel anjutnya adal ah sebanyak jumlah karakter "T" Pada tabel $\mathrm{OH}$ pada yaitu 2 , dapat dilihat pada tabel 4 .

TABEL 4. LANGKAH 3

$$
\text { Langkah ke } 3
$$

\begin{tabular}{l|l|l|l|l|l|l|l|l|l|l|l|l|l}
\hline $\begin{array}{l}\text { Posisi } \\
\text { Teks }\end{array}$ & 1 & 2 & 3 & 4 & 5 & 6 & 7 & 8 & 9 & 10 & 11 & 12 & 13 \\
\hline
\end{tabular}

\begin{tabular}{l|l|l|l|l|l|l|l|l|l|l|l|l|l|l}
\hline Teks & $\mathrm{P}$ & $\mathrm{E}$ & $\mathrm{R}$ & $\mathrm{I}$ & $\mathrm{A}$ & $\mathrm{R}$ & $\mathrm{T}$ & $\mathrm{H}$ & $\mathrm{R}$ & $\mathrm{I}$ & $\mathrm{T}$ & $\mathrm{I}$ & $\mathrm{S}$ \\
\hline Pattern & & & & & & & $\mathrm{R}$ & $\mathrm{I}$ & $\mathrm{T}$ & $\mathrm{I}$ & $\mathrm{S}$ & & \\
\hline
\end{tabular}

4. Pada pergeseran Ke-4 karakter "S" pada pattern cocok dengan karakter "S" dan pada teks maka pergeseran selanjutnya dimundurkan menjadi satu langkah.

5. Pada pergeseran selanjutnya dilakukan sampai pada pergeseran ke-8 karakter "R" pada pattern dengan karakter "R" pada text cocok, dapat dilihat pada tabel 5 .

TABEL 5. LANGKAH 4

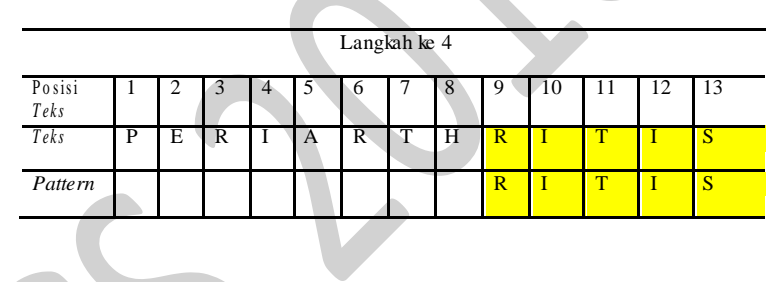

\section{METODOLOGI PENELITIAN}

Dalam melaksanakan penelitian, penulis menggunakan metode Waterfall karena proses pengembangan menggunakan model fase one by one, sehingga meminimalisir kesalahan yang mungkin terjadi dan tahapan pengerjaan dapat dilihat pada alur penelitian yang dapat dilihat pada Gambar 1 sebagai berikut:

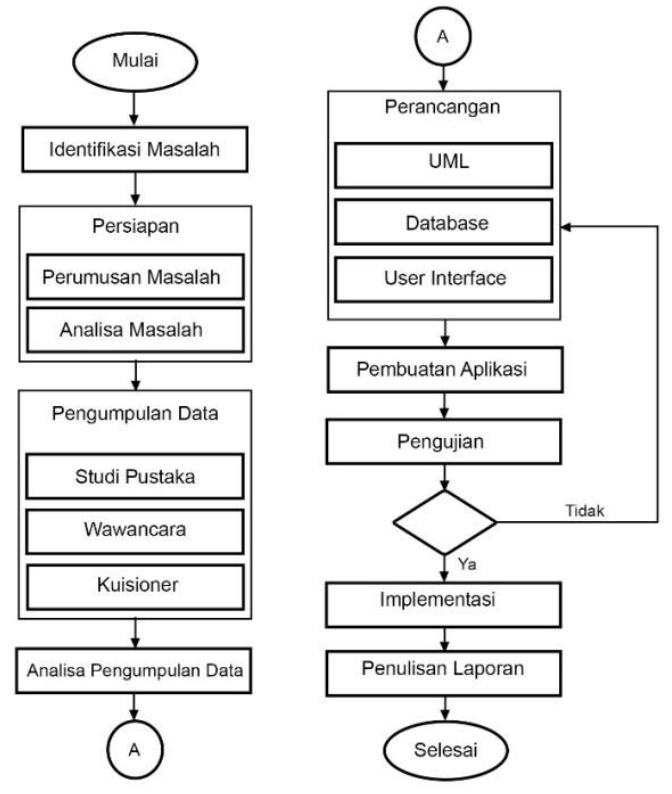

Gambar 1. Alur Penelitian 


\section{IDENTIFIKAS I MASALAH}

Identifikasi masalah adalah salah satu cara mengidentifikasi semua masalah-masalah yang terkait dengan penelitian yang akan di buat di antaranya Beberapa istilah buku Informasi Spesialite Obat (ISO) masih berbentuk buku manual sehingga dibutuhkan Aplikasi dalam bentuk Mobile Application untuk memudahkan pencarian dalam jangka waktu yang singkat.

\section{A. Perumusan dan Analisa Masalah}

Berdasarkan latar belakang penulis dapat merumuskan suatu masalah yaitu kurangnya efisiensi waktu saat penggunaan buku Informasi Spesialite Obat (ISO) Manual yang masih dalam bentuk buku sehingga menghambat dan memperlambat pencarian. Setelah dirumuskan Masalah langkah selanjutnya adalah menganalisa masalah yang terdapat pada penelitian yang dilakukan. Peneliti menganalisa suatu masalah dalam Informasi Spesialite Obat (ISO) Manual untuk dijadikan sebagai sarana media aplikasi alternatif dalam memudahkan pencarian dalam bentuk digital.

\section{B. Pengumpulan Data}

Ada tiga tahap dalam melakukan pengumpulan data yaitu :

1. Studi Pustaka

Penulis melakukan pengumpulan dari sebuah data dengan menggunakan media-media yang terutama dari buku, jurnal, modul, buku dan pencarian data dari situs internet yang berkaitan dengan Informasi Spesialite Obat (ISO) dengan Mobile Apllication

2. Wawancara

Penulis melakukan Tanya jawab secara langsung kepada perwakilan Apoteker yang berkaitan dengan Aplikasi Sistem Informasi Spesialite Obat (ISO) Indonesia.

\section{Kuisioner}

Penulis memberikan kuisoner sebelum penelitian dan setelah penelitian secara langsung kepada apoteker dan asisten apoteker terkait kebutuhan dalam aplikasi sistem Informasi Spesialite Obat (ISO) Indonesia.

\section{Analisa Pengumpulan Data}

Pada tahap ini peneliti menjelaskan dari pengumpulan data yang sudah dikumpulkan. Tujuan dari Analisa Pengumpulan Data adalah untuk mencari parameter kualitas layanan yang benar-benar baik dalam pengumpulan informasi.

\section{Pengujian}

Setelah aplikasi sudah selesai dibuat, langkah selanjutnya adalah pengujian terhadap aplikasi. Pengujian aplikasi dilakukan untuk mengetahui apakah aplikasi yang telah dibuat sudah berjalan dengan benar atau tidak. Jika pengujian tersebut sudah benar, maka aplikasi tersebut sudah dapat digunakan oleh siswa maupun guru. Namun apabila belum sesuai, maka kembali ke tahap perancangan dan melihat kekurangan apa yang harus diperbaiki.

\section{E. Implementasi}

Pada tahapan ini, sistem yang sudah berhasil dalam proses pengujian diimplementasikan di Apotek Amanah.

\section{ANALISA PERANCANGAN S ISTEM}

\section{A. Perangkat Keras (Hardware)}

Perangkat keras yang digunakan untuk me mbuat aplikasi ini adalah :

1. Processor : Intel(R) Core(TM) i3-2430M CPU @

$\begin{array}{lll} & & 1.70 \mathrm{GHz} 2.40 \mathrm{Ghz} \\ \text { 2. } & \text { RDD } & : 500 \mathrm{~GB} \\ \text { 4. } & \text { VGA } & : 4 \mathrm{~GB} \\ & : \text { NVIDIA GeForce } 920 \mathrm{M}\end{array}$

B. Perangkat Lunak (Software)

1. Sistem Operasi : Windows 10

2. Software : Adobe Photoshop CC 2015, Eclipse, ADT 8.0.1, Android SDK, Java Development Kit 1.6.0.

\section{Kebutuhan Perangkat Sistem}

Kebutuhan perangkat keras dan perangkat lunak yang dibutuhkan sistem, yaitu:

1. Smartphone yang memiliki Minimum Android OS 2.2 (Froyo).

2. Kapasitas RAM pada Smartphone Minimu m 512 MB.

3. Layar yang digunakan Minimum 4.0 inches, Maksimum 6,2 inches.

4. Memory penggunaan Aplikasi maksimal $5 \mathrm{MB}$.

Use case diagram adalah gambaran graphical dari beberapa atau semua aktor, use case, dan interaksi diantara komponen-komponen tersebut yang memperkenalkan suatu sistem yang akan dibangun digunakan untuk menjelaskan bagaimana langkahlangkah yang seharusnya dikerjakan oleh sistem. Use case diagram menjelaskan manfaat suatu sistem jika dilihat menurut pandangan orang yang berada di luar sistem. Diagram ini menunjukkan fungsionalitas suatu sistem atau kelas dan bagaimana sistem tersebut 
berinteraksi dengan dunia luar. Adapun use case pada aplikasi ini adalah sebagai berikut:

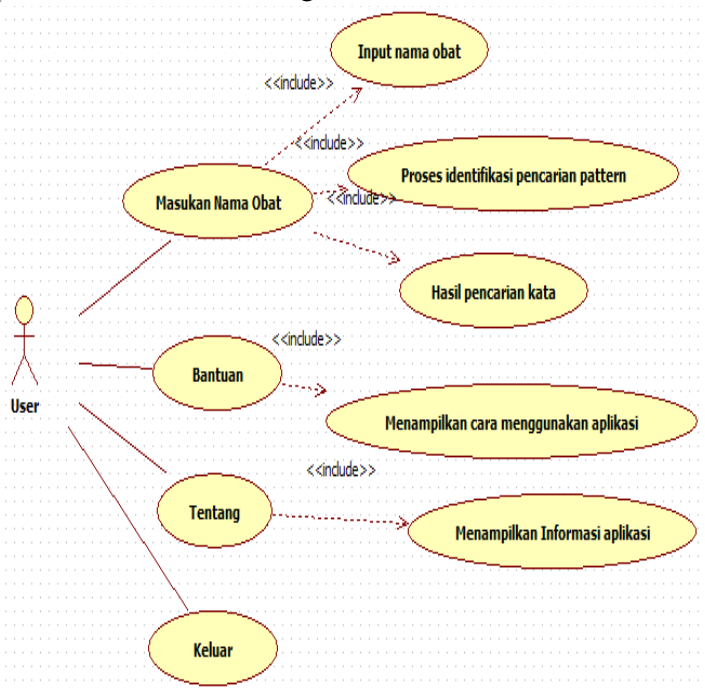

Gambar 2. Use case

\section{IMPLEMENTAS I}

A. Tampilan Logo Sistem Informasi Spesialite Obat Digital

Tampilan diatas adalah logo dari Aplikasi Sistem Informasi Spesialite Obat Digital yang ada pada tampilan Menu pencarian sebagai identitas awal dari Apliksi yang ada pada Smartphone yang digunakan Apoteker dan Asisten Apoteker dalam menggunakan untuk mencari Informasi dari obat pada Apotek Amanah, dapat dilihat pada Gambar 3.

\section{ISO Digitap \\ Apotek Amanah \\ $1=$}

Gambar 3. T ampilan Logo

B. Splash Screen Menu Utama

Di dalam tampilan awal program ini adalah tampilan dimana aplikasi pertama kali run dan akan menampilkan Splash Screen dari Aplikasi yang dijalankan menuju ke menu utama, adapun tampilan tersebut adalah dapat dilihat pada Gambar 4.

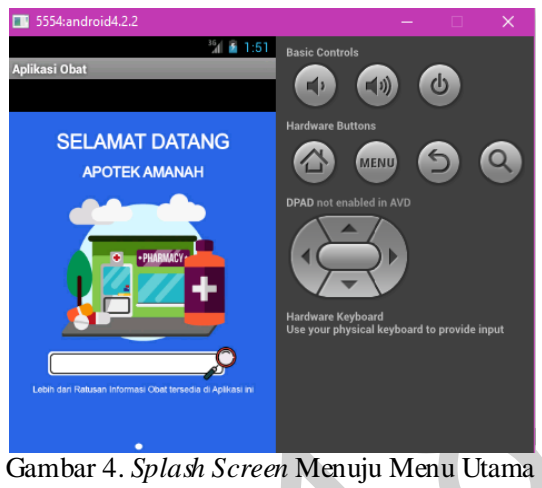

\section{Tampilan Menu Utama}

Saat user akan diberikan tampilan menu utama, beberapa menu pilihan yang dapat dipilih user bisa memilih salah satu menu dari empat menu yang telah disediakan, adapun tampilan tersebut dapat dilihat pada Gambar 5.

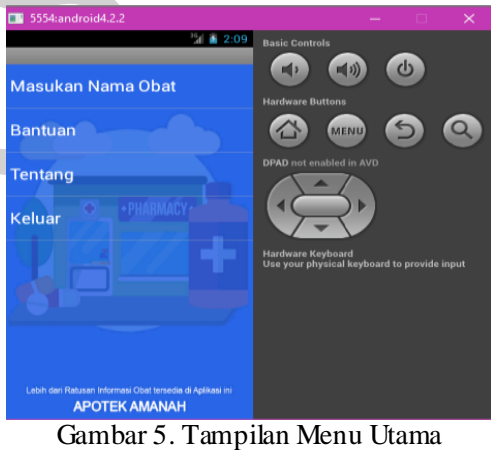

\section{Tampilan Menu Masukan Nama Obat}

Halaman selanjutnya adalah halaman menu masukan nama obat dimana terdapat Input text, button cari dan kolom Indikasi adapun tampilan tersebut dapat dilihat pada Gambar 6.

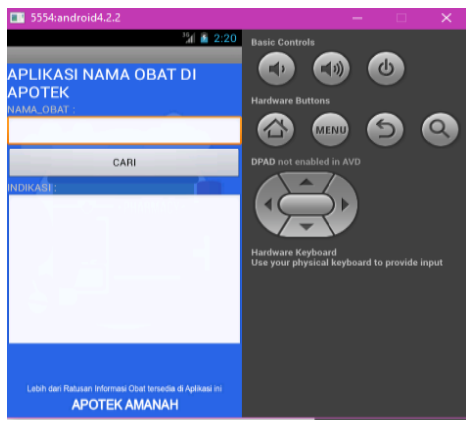

Gambar 6. Tampilan Menu Masukan Nama Obat

\section{E. Tampilan Menu Keluar}


Halaman selanjutnya adalah menu Keluar yang berfungsi untuk pengguna untuk mengakhiri atau keluar dari Aplikasi ISO Digital. Adapun tampilan tersebut dapat dilihat pada Gambar 7.

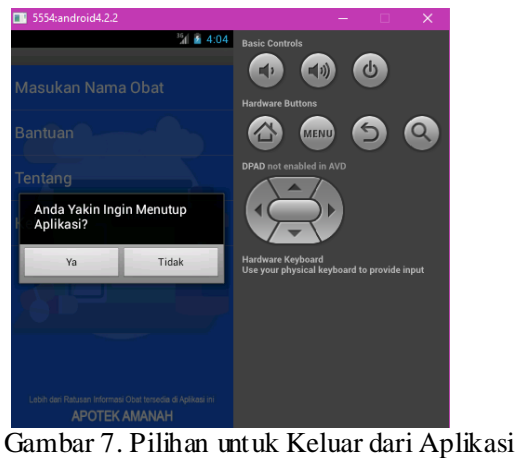

\section{F. Pengujian}

Pengujian sistem dilakukan untuk memeriksa apakah setiap ko mponen atau elemen-elemen di dalam hasil program telah bekerja dan berfungsi dengan baik dan sesuai yang diharapkan. Cara pengujiannya yakni dengan menggunakan metode black box testing, dengan memberikan input kedalam sistem dan melihat apakah hasil output yang dihasilkan sudah sesuai dengan apa yang diharapkan atau belum. Hasil dari pengujian terhadap sistem akan ditampilkan ke dalam bentuk Tabel 6.

TABEL 6. PENGUJIAN ISO DIGITAL

\begin{tabular}{|c|c|c|c|}
\hline Butir Menu & Pengujian & Hasil & Keterangan \\
\hline $\begin{array}{l}\text { Tampilan } \\
\text { Splash Screen } \\
\text { saat membuka } \\
\text { awal Aplikasi. }\end{array}$ & $\begin{array}{l}\text { User } \\
\text { menjalankan } \\
\text { Aplikasi ISO } \\
\text { Digital. }\end{array}$ & $\begin{array}{l}\text { Menampilkan } \\
\text { Splash Screen } \\
\text { dan menuju ke } \\
\text { halaman menu } \\
\text { utama. }\end{array}$ & BERHASIL \\
\hline $\begin{array}{l}\text { Tampilan } \\
\text { akses menu } \\
\text { utama. }\end{array}$ & $\begin{array}{l}\text { User } \\
\text { menjalankan } \\
\text { Aplikasi ISO } \\
\text { Digital. }\end{array}$ & $\begin{array}{l}\text { Menampilkan } \\
\text { menu utama } \\
\text { dan terdapat } 4 \\
\text { menu pilihan. }\end{array}$ & BERHASIL \\
\hline $\begin{array}{l}\text { Tampilan } \\
\text { akses menu } \\
\text { masukan } \\
\text { nama obat. }\end{array}$ & $\begin{array}{l}\text { User } \\
\text { menjalankan } \\
\text { dan memilih } \\
\text { menu } \\
\text { masukan } \\
\text { nama obat } \\
\text { lalu } \\
\text { menuliskan } \\
\text { nama obat } \\
\text { yang } \\
\text { diinginkan. }\end{array}$ & $\begin{array}{l}\text { Menampilan } \\
\text { Informasi Obat } \\
\text { secara lengkap } \\
\text { dan benar. }\end{array}$ & BERHASIL \\
\hline
\end{tabular}

\begin{tabular}{|l|l|l|l|}
\hline $\begin{array}{l}\text { Tampilan } \\
\text { akses menu } \\
\text { Bantuan. }\end{array}$ & $\begin{array}{l}\text { User } \\
\text { menjalankan } \\
\text { dan memilih } \\
\text { menu } \\
\text { bantuan. }\end{array}$ & $\begin{array}{l}\text { Menampilan } \\
\text { panduan } \\
\text { penggunaan } \\
\text { Aplikasi ISO } \\
\text { Digital. }\end{array}$ & BERHASIL \\
\hline $\begin{array}{l}\text { Tampilan } \\
\text { akses menu } \\
\text { Tentang. }\end{array}$ & $\begin{array}{l}\text { User } \\
\text { menjalankan } \\
\text { dan memilih } \\
\text { menu } \\
\text { Tentang. }\end{array}$ & $\begin{array}{l}\text { Menampilan } \\
\text { Informasi } \\
\text { Apotek dan } \\
\text { Versi Aplikasi } \\
\text { ISO Digital. }\end{array}$ & BERHASIL \\
\hline $\begin{array}{l}\text { Tampilan } \\
\text { Button unt uk } \\
\text { Keluar. }\end{array}$ & $\begin{array}{l}\text { User } \\
\text { memilih } \\
\text { Button }\end{array}$ & $\begin{array}{l}\text { Aplikasi ISO } \\
\text { Digital akan } \\
\text { Keluar. }\end{array}$ & BERHASIL \\
\hline
\end{tabular}

\section{KES IMPULAN DAN SARAN}

\section{A. Kesimpulan}

Kesimpulan yang dapat diambil dari Sistem Informasi Spesialite Obat Digital adalah sebagai berikut :

1. Tercapainya Aplikasi Sistem Informasi Spesialite Obat Digital menggunakan Algoritma Boyer Moore Berbasis Mobile Application secara efektif dan efisien sehinngga mempermudah Apoteker dan Asisten Apoteker dalam menggunakannya.

2. Sudah diterapkannya Aplikasi Sistem Informasi Spesialite Obat Digital menggunakan Algoritma Boyer Moore Berbasis Mobile Application sebagai acuan pencarian obat di Apotek Amanah.

3. Setelah dilakukan kuesioner hasil kerja aplikasi pada penelitian ini, maka didapatkan 88,83\% responden memberikan penilaian yang baik dalam kinerja aplikasi Sistem Informasi Spesialite Obat Digital dalam menangani permasalahan terkait Informasi obat berbas is Mobile Application yang belum dimiliki dan diketahui oleh Apoteker dan Asisten Apoteker.

\section{B. Saran}

Untuk pengembangan aplikasi ini ke depannya, berikut beberapa saran yang dianjurkan :

1. Untuk ke depannya aplikasi ini bisa disempurnakan dengan memperbanyak lag $\mathrm{i}$ Feature yang lebih lengkap dan banyak untuk menunjang kegiatan di Apotek.

2. Dalam proses untuk mendapatkannya, aplikasi ini dapat diunggah ke Market atau Play Store dari Android. 
[1]. Citra Puji Lestari, Nelly Astuti Hasibuan, Guidio Leonarde Ginting. Perancangan Aplikasi Kamus Istilah Medis Berbasis Android Dengan Algoritma Boyer-Moore. Jurnal INFOTEK, Volume II, Nomor 3, Juni 2016.

[2]. Safat N H. 2012. Pemrograman aplikasi mobile smartphone dan tablet PC berbasis Android. Bandung. Informatika. 2012. Hlm, 30.

[3]. Satyaputra Alfa, Eva M A. Java for Beginners With Eclipse 4.2. Jakarta. PT Elex Media Komputindo. Hlm 49-51. 2012.

[4]. Triady D. Bedah tuntas fitur Android. Jakarta. Galang press Group. 130. 2013.

[5]. Eza Rahmanita, S.T., M.T. Pencarian String Mengunakan Algoritma Boyer Moore pada Dokumen. Jurnal Ilmiah NERO Vol. 1 No. 1. Universitas Trunojoyo, Madura. 2014. 